\title{
Diet, vegetarian food and prostate carcinoma among men in
} Taiwan

\section{YC Chen ${ }^{1,2}, \mathrm{Cl}$ Chiang ${ }^{2}, \mathrm{RS} \mathrm{Lin}^{3}$, YS Pu${ }^{4}$, MK Lai ${ }^{4}$ and F-C Sung ${ }^{*, 2,3,5}$}

'Chia Nan University of Pharmacy and Science, 60 Erh-Jen Road, Jen Te, Tainan, Taiwan 71 7, Taiwan; ${ }^{2}$ Institutes of Environmental Health, National Taiwan University College of Public Health, Taipei, Taiwan 100, Taiwan; ${ }^{3}$ Preventive Medicine, National Taiwan University College of Public Health, Taipei, Taiwan 100, Taiwan; ${ }^{4}$ Department of Urology, National Taiwan University College of Medicine, I Jen-Ai Road Section I, Taipei, Taiwan I00, Taiwan; ${ }^{5}$ Institute of Environmental Health, China Medical University College of Public Health, 91 Hsueh-Shih Road, Taichung, Taiwan 404, Taiwan

In a case-control study in a veterans hospital in Taiwan, we compared 237 histology-confirmed prostate carcinoma cases with 48 I controls, frequency matched by age, for their consumption of vegetarian food, namely soybean products, rice, wheat protein and other vegetables. The multivariable logistic regression analysis showed a significant association with such food (odds ratio $(O R)=0.67,95 \%$ confidence interval $(C l)=0.47,0.94)$. This beneficial effect presented for men with body mass index (BMI) $\leqslant 25 \mathrm{~kg} \mathrm{~m}^{-2}(\mathrm{OR}=0.50,95 \% \mathrm{Cl}=0.32,0.76)$ but not for men with greater BMl. The OR of prostate carcinoma for men with BMI $\leqslant 25 \mathrm{~kg} \mathrm{~m}^{-2}$ was $1.74(95 \% \mathrm{Cl}=1.2 \mathrm{I}, 2.5 \mathrm{I})$, compared with men with higher BMI $\left(>25 \mathrm{~kg} \mathrm{~m}^{-2}\right)$. Other significant risk factors associated with the disease included higher income $(\mathrm{OR}=2.40,95 \% \mathrm{Cl}=1.07,5.42)$, physical activity $(\mathrm{OR}=1.75,95 \% \mathrm{Cl}=1.08$, 2.83), being married $(\mathrm{OR}=2.49,95 \% \mathrm{Cl}=1.40,4.43)$ and coffee consumption $(\mathrm{OR}=1.88,95 \% \mathrm{Cl}=1.07,3.30)$. Stratified analysis also showed that the consumption of fish/shellfish had an adverse association for men with higher BMI. This study suggests that the intake of the low fat local vegetarian food has a protective effect against prostate carcinoma for thin men in this study population. British Journal of Cancer (2005) 93, 1057-106I. doi:I0.1038/sj.bjc.6602809 www.bjcancer.com

Published online 4 October 2005

(c) 2005 Cancer Research UK

Keywords: body mass; case-control study; local vegetarian food; prostate neoplasm; Taiwan

Diet has been associated with cancers of the prostate, colorectum, breast and other sites (Doll and Peto, 1981). Although potential dietary risk factors for high-fat and low-fibre foods have shown associations with prostate carcinoma in Western countries (Howell, 1974; Giovannucci et al, 1995; Whittemore et al, 1995; Parkin et al, 1999; Bostwick et al, 2004), their role remains unclear for Asian men. Investigation of the disease in populations with lower incidence may provide further insight into its aetiology with relation to diet, particularly as the food consumed in Taiwan is different from that in Western countries.

Asian migrants to the US have shown an appreciable rise in prostate carcinoma incidence, perhaps due to their increasingly westernised lifestyle in recent decades. The incidence of prostate carcinoma in Taiwan increased from 2.3 per 100000 in 1985 to 12.8 per 100000 in $1999 v s 118.2$ per 100000 in men in the US in $1992-$ 1996 (Ries et al, 1999; Department of Health, 2002). This increase is generally attributed to the westernised lifestyle and prostatespecific antigen (PSA) testing in urology clinics in Taiwan. However, despite the increasing incidence in Taiwan, it remains relatively rare as compared with Western countries.

A prospective Hawaiian study (Severson et al, 1989) found that a decreased risk of the disease was associated with a high

*Correspondence: Dr F-C Sung, Institute of Environmental Health, China Medical University College of Public Health, 91 Hsueh Shih Road, Taichung, Taiwan 404, Taiwan;

E-mail: fcsung@mail.cmu.edu.tw, sung@ha.mc.ntu.edu.tw

Revised 20 July 2005; accepted 17 August 2005; published online 4 October 2005 consumption of rice or tofu, which are common low-fat items in Chinese meals, including local vegetarian food in Taiwan, with various products derived from soybean and wheat protein, together with nuts, peas, vegetables and pickles. This study investigated the association of prostate carcinoma with the consumption of such food, which has not previously been evaluated (Sung et al, 1999).

\section{MATERIALS AND METHODS}

\section{Subjects}

The cases studied were men, aged 50 years or older, with histologyconfirmed prostate adenocarcinoma, and newly identified in the Division of Urology, Department of Surgery at a veterans medical centre in Taipei, Taiwan between August 1996 and July 1998. A total of 259 cases were identified, of whom 22 patients refused to participate or did not complete the interview.

Eligible controls were patients admitted to the same hospital for causes other than malignant diseases. Controls with benign prostate hyperplasia, cardiovascular disease or hormonal disorders were also excluded from this study. Patients with inguinal hernia and renal stones were not excluded. For each case, two hospital controls were selected by frequency match, and were aged 50 years or older. Among the 518 controls, 481 completed the interview, including patients from the Division of Orthopedics and/or Emergency Services (40.5\%), Department of Ophthalmology $(38.5 \%)$ and other departments $(21.0 \%)$. 


\section{Data collection}

With the consent of the subjects, interviews were conducted in person by trained interviewer using standard questionnaires while the participants were in hospital. Adapted from a previous pilot study (Sung et al, 1999), the questionnaires included sociodemographic characteristics, history of occupational chemical exposure, tobacco and alcohol use, diet, physical activity, height and weight history, medical history and family history of prostate cancer. Dietary intake history was determined mainly using a semiquantitative food frequency questionnaire. The questionnaire asked for the most frequently consumed foods: pork, beef, fish and shellfish, eggs, vegetables, fruits, carrots, dairy products and entrails, etc. Subjects were asked to recall the consumption of each food item in the past 10 years and determine, compared to other male acquaintances, whether they consumed a greater amount, a moderate amount, less or none at all. The questionnaire also contained some beverages including milk, coffee, soybean milk, rice milk and tea, etc. Daily frequencies and years of drinking and coffee and tea consumptions were measured.

One question specifically asked was about the subjects' consumption patterns of the local vegetarian food, named 'Zhai' or 'Sue' food in Chinese, abstaining from meat for all meals or for every first day and 15th day each month. We also asked them to determine whether they consumed this type of food in greater, moderate, less amount or none at all. The local vegetarian food in Taiwan is a commercially available unique style of food consisting mainly of products made of soybean and protein of wheat flour. Peanuts, beans, peas, pickles and vegetables stir-fried with vegetable oil are other frequently consumed items in this kind of meals. Plain cooked rice is usually the main staple in a vegetarian meal. Rice soup is often served for breakfast. Buddhist families (not necessarily priests, monks or nuns) are most likely to consume this type of food. Other lay people also consume this local vegetarian food, particularly for breakfast, but may include milk and/or eggs, such as preserved eggs (thousand-year eggs in lay language) or boiled salted eggs.

The major items of physical activities in the questionnaire included leisure-time exercises, work or leisure-time hobbies such as gardening, yard work, carpentry and other domestic chores requiring physical exertion. These were scored and then categorised as sedentary, low, moderate or high.

\section{Data analysis}

The data analyses began with distributions of responses and risk factors to estimate differences in cases and controls. For the comparison of age, subjects were grouped into two groups $(<70 \mathrm{vs}$ $\geqslant 70$ years) based on the age of cases and controls at diagnosis. In this study, participants were mainly veterans (83\%). Since the tumorigenesis may have association with the body weight, body mass indexes (BMI) values taken 1 year prior to the interview about the disease and at ages 40-45 years were used in the data analysis and also grouped into two levels $\left(>25 v \mathrm{~s} \leqslant 25 \mathrm{~kg} \mathrm{~m}^{-2}\right.$ ) based on the normal BMI range for Taiwanese males. Physical activity was considered as the combination of work and exercises and was classified into two levels (low/moderate $v s$ high).

Univariate analyses were used to identify the potential covariates between the folk style vegetarian food and the risk of prostate carcinoma. The strength of the association between prostate carcinoma and potential risk factors was measured, using logistic regression models, in terms of odds ratios (OR) and $95 \%$ confidence interval (CI). Significant variables identified from the univariate analyses were included as covariates in multivariable logistic regression models. With age and BMI being included, the downward stepwise modelling was used to determine the best predictors of risk for prostate carcinoma. The least significant variables were deleted one at a time. The final model was derived based on significance testing. Data were analysed using SAS for Windows Version 8.0 (SAS Institute, Inc., Cary, NC, USA).

\section{RESULTS}

More than half of the subjects were aged 70 years or older and approximately 64 percent of participants were retired. Compared with controls, cases had higher education, higher rate of marriage, more children, higher proportion of religious affiliation and a higher family income (Table 1). Cases also had higher physical activity levels than controls. However, cases had a lower BMI than controls. Fewer cases than controls were current smokers. Only a small portion of subjects drank coffee, but the use was significantly higher in cases than in controls $(P=0.02)$.

There were no significant differences between cases and controls in the consumption of most dietary beverage variables (Table 2). Cases consumed Taiwanese folk style vegetarian food more often than controls did (65.5 vs 55.3\%; OR $=0.66,95 \%, \mathrm{CI}=0.48,0.91)$. Although a larger percentage of cases drank tea and milk than controls, these differences were not significant either.

Risk factors for prostate carcinoma that remained significant following multivariate conditional logistic regression without interaction terms were higher income, pursuing physical activities, being married, drinking coffee and partaking of folk style vegetarian food (Table 3 ). Men with high BMI were at an elevated risk of the disease $(\mathrm{OR}=1.74, \mathrm{CI}=1.21,2.51)$. The consumption of the folk style vegetarian food showed a significant protective effect $(\mathrm{OR}=0.67,95 \% \mathrm{CI}=0.47,0.94)$. This protective effect was modified by BMI, significant for men with lower BMI $(\mathrm{OR}=0.50,95 \% \mathrm{CI}=0.32,0.76)$, but not for men with higher BMI $(\mathrm{OR}=1.25,95 \% \mathrm{CI}=0.66,2.37)$.

\section{DISCUSSION}

The present case-control study found prostate carcinoma to be negatively associated with the consumption of Taiwanese folk style vegetarian food and BMI, but positively associated with income, being married, coffee consumption and physical activities. Different from other studies (Whittemore et al, 1995), this study found no significant increase in the meat intake among cases.

Previous studies on the relationship between physical activities and prostate carcinoma have yielded conflicting results (Lee et al, 1992; Ilic et al, 1996). Exercise among the elderly in Taiwan is usually a leisure-time activity among the affluent. Physical activities may also be related to a lower BMI. One cohort study and one case-control study have supported a relationship between heavy weight, high BMI and increased risk of prostate carcinoma (Chyou et al, 1994; Gronberg et al, 1996). Some case-control studies suggested an absence of this association (Whittemore et al, 1995; Meyer et al, 1997). We found that, with BMI and the folk vegetarian food as interaction terms in the model, body weight appears to have a strong effect, modifying the protective effect of the folk food. To our knowledge, this is an interesting issue that has not been reported. It is not clear why the beneficial effect of Taiwanese folk vegetarian food on prostate carcinoma is limited to thin men.

Giovannucci et al (1993) strongly suggested that dietary fat, in particular, the fatty acid in red meat, increases the risk of prostate tumorigenesis two-fold. Several other studies also have demonstrated a similar fat intake association (Gann et al, 1994; Vlajinac et al, 1997).

A comprehensive case-control study found a strong trend of risk with fat intake in all ethnic groups, including for AsianAmerican men (Whittemore et al, 1995). It suggests an increase in prostate carcinoma risk as men migrate from a low dietary-fat to high dietary-fat culture. The incidence of prostate carcinoma for Chinese men in Taiwan (Department of Health, 2002) is far lower 
Table I Sociodemographic characteristics and lifestyle of prostate carcinoma cases and controls in Taiwan, 1996-1998

\begin{tabular}{|c|c|c|c|}
\hline Characteristic & $\begin{array}{c}\text { Cases } N=237 \\
n(\%)\end{array}$ & $\begin{array}{c}\text { Controls } N=48 \mathrm{I} \\
n(\%)\end{array}$ & $P$-value ${ }^{a}$ \\
\hline \multicolumn{4}{|l|}{ Age, years } \\
\hline $\begin{array}{l}\text { Mean } \pm \text { s.d. } \\
<70\end{array}$ & $\begin{array}{l}72.2 \pm 6.1 \\
95(40.1)\end{array}$ & $\begin{array}{l}71.1 \pm 5.8 \\
220(45.7)\end{array}$ & $\begin{array}{l}0.03 \\
0.15\end{array}$ \\
\hline$\geqslant 70$ & $142(59.9)$ & $261(54.6)$ & \\
\hline \multicolumn{4}{|l|}{ Veterans } \\
\hline No & $42(17.8)$ & $79(16.5)$ & 0.66 \\
\hline Yes & $194(82.2)$ & $400(83.5)$ & \\
\hline \multicolumn{4}{|l|}{ Education, years } \\
\hline$\leqslant 6$ & $76(32.1)$ & $227(47.2)$ & 0.001 \\
\hline $7-12$ & 87 (36.7) & $150(31.2)$ & \\
\hline$>12$ & $70(29.5)$ & $97(20.2)$ & \\
\hline Unknown & $4(1.7)$ & $7(1.4)$ & \\
\hline \multicolumn{4}{|l|}{ Married } \\
\hline No & $17(7.2)$ & $78(16.2)$ & 0.001 \\
\hline Ever married & $220(92.8)$ & 401 (83.4) & \\
\hline Unknown & $0(0.0)$ & $2(0.4)$ & \\
\hline \multicolumn{4}{|l|}{ Having children } \\
\hline Yes & 207 (87.3) & $380(79.0)$ & 0.003 \\
\hline No & $27(\mid 1.4)$ & $99(20.6)$ & \\
\hline Unknown & $3(1.3)$ & $2(0.4)$ & \\
\hline \multicolumn{4}{|l|}{ Religious } \\
\hline Buddhism/Taoism & $88(37.1)$ & $152(31.6)$ & 0.11 \\
\hline Others/none & $145(61.2)$ & $326(67.8)$ & \\
\hline Unknown & $4(1.7)$ & $3(0.6)$ & \\
\hline \multicolumn{4}{|l|}{ Occupation } \\
\hline Retired & |5| (63.7) & $306(63.6)$ & 0.3 \\
\hline Government employee & $19(8.0)$ & $51(10.6)$ & \\
\hline Business & $50(21.1)$ & $97(20.2)$ & \\
\hline Others & $16(6.7)$ & $19(3.9)$ & \\
\hline Unknown & I (0.5) & $8(1.7)$ & \\
\hline \multicolumn{4}{|l|}{ Family income } \\
\hline Low/moderate & $210(88.6)$ & $420(87.3)$ & 0.005 \\
\hline Higher & $16(6.8)$ & II (2.3) & \\
\hline Unknown & II (4.6) & $50(10.4)$ & \\
\hline \multicolumn{4}{|l|}{ BMI, at age $40-45$ years } \\
\hline$\leqslant 25 \mathrm{~kg} \mathrm{~m}^{2}$ & $173(73.0)$ & $323(67.2)$ & 0.11 \\
\hline$>25 \mathrm{~kg} \mathrm{~m}^{2}$ & $64(27.0)$ & $158(32.8)$ & \\
\hline \multicolumn{4}{|l|}{ BMI, I year before interview } \\
\hline$\leqslant 25$ & 165 (69.6) & $285(59.3)$ & 0.007 \\
\hline$>25$ & $72(30.4)$ & $196(40.7)$ & \\
\hline \multicolumn{4}{|l|}{ Physical activity } \\
\hline Low/moderate & $196(82.7)$ & $425(88.4)$ & 0.02 \\
\hline Higher & $389(16.0)$ & $49(10.2)$ & \\
\hline Unknown & $3(1.3)$ & $7(1.4)$ & \\
\hline \multicolumn{4}{|l|}{ Smoking } \\
\hline Yes & $64(27.0)$ & $164(34.1)$ & 0.05 \\
\hline Ever smoking & 93 (39.2) & $147(30.6)$ & \\
\hline No & $80(33.8)$ & $170(35.3)$ & \\
\hline \multicolumn{4}{|l|}{ Alcohol } \\
\hline Yes & 61 (25.7) & I42 (29.5) & 0.32 \\
\hline No & 174 (73.5) & $339(70.5)$ & \\
\hline Unknown & $2(0.8)$ & $0(0.0)$ & \\
\hline \multicolumn{4}{|l|}{ Coffee } \\
\hline Yes & $31(13.1)$ & $36(7.5)$ & 0.02 \\
\hline No & $206(86.9)$ & $443(92.1)$ & \\
\hline Unknown & $0(0.0)$ & $2(0.4)$ & \\
\hline
\end{tabular}

Table I (Continued)

\begin{tabular}{lccc}
\hline Characteristic & $\begin{array}{c}\text { Cases } \mathbf{N}=\mathbf{2 3 7} \\
\boldsymbol{n}(\%)\end{array}$ & $\begin{array}{c}\text { Controls } \mathbf{N}=\mathbf{4 8} \mathbf{I} \\
\boldsymbol{n}(\%)\end{array}$ & $\boldsymbol{P}^{\text {-value }}$ \\
\hline Tea & & & \\
Yes & $113(47.7)$ & $208(43.2)$ & 0.26 \\
No & $124(52.3)$ & $273(56.8)$ & \\
Any chemical exposure & & & \\
Yes & $74(31.2)$ & $161(33.5)$ & 0.57 \\
No & $162(68.4)$ & $320(66.5)$ & \\
Unknown & I (0.4) & $0(0.0)$ & \\
\hline
\end{tabular}

${ }^{a}$ Chi-square tests except using $t$-test for the comparison of means. s.d. = standard deviation. $\mathrm{BMI}=$ body mass index, $\mathrm{kg} \mathrm{m}^{-2}$.

Table 2 Odds ratios (95\% confidence intervals) for selected dietary consumption variables for prostate carcinoma among men in Taiwan, 1996-1998

\begin{tabular}{|c|c|c|c|c|}
\hline & $\begin{array}{c}\begin{array}{c}\text { Cases } \\
N=237\end{array} \\
n(\%)\end{array}$ & $\begin{array}{c}\text { Controls } \\
N=48 \text { I } \\
n(\%)\end{array}$ & $\begin{array}{c}\text { Crude } \\
\text { OR }(95 \% \mathrm{Cl})\end{array}$ & $\begin{array}{l}\text { Age-adjusted } \\
\text { OR }(95 \% \mathrm{CI})\end{array}$ \\
\hline \multicolumn{5}{|l|}{ Pork } \\
\hline$\geqslant$ Moderate & $191(80.6)$ & $373(77.6)$ & I. $18(0.8,1.74)$ & $1.24(0.84,1.84)$ \\
\hline Less, none & $46(19.4)$ & $106(22.0)$ & 1.0 & 1.0 \\
\hline Unknown & $0(0.0)$ & $2(0.4)$ & & \\
\hline \multicolumn{5}{|l|}{ Beef } \\
\hline$\geqslant$ Moderate & $154(65.0)$ & $308(64.1)$ & $1.04(0.75,1.43)$ & $1.05(0.76,1.46)$ \\
\hline Less, none & $83(35.0)$ & $172(35.7)$ & 1.0 & 1.0 \\
\hline Unknown & $0(0.0)$ & I (0.2) & & \\
\hline \multicolumn{5}{|l|}{ Egg } \\
\hline$\geqslant$ Moderate & $178(75.1)$ & $360(74.9)$ & $1.00(0.7,1.43)$ & I.01 $(0.70,1.44)$ \\
\hline Less, none & $59(24.9)$ & $119(24.7)$ & 1.0 & 1.0 \\
\hline Unknown & $0(0.0)$ & $2(0.4)$ & & \\
\hline \multicolumn{5}{|l|}{ Fish/shellfish } \\
\hline$\geqslant$ Moderate & $161(67.9)$ & $317(65.9)$ & $1.09(0.78,1.52)$ & $1.12(0.80,1.56)$ \\
\hline Less, none & $76(32.1)$ & 163 (33.9) & 1.0 & 1.0 \\
\hline Unknown & $0(0.0)$ & I (0.2) & & \\
\hline \multicolumn{5}{|l|}{ Vegetables/fruits } \\
\hline$\geqslant$ Moderate & $212(89.5)$ & $428(89.0)$ & $1.03(0.62,1.7 \mathrm{I})$ & $1.03(0.62,|.7|)$ \\
\hline Less/none & $25(10.5)$ & $52(10.8)$ & 1.0 & 1.0 \\
\hline Unknown & $0(0.0)$ & I $(0.2)$ & & \\
\hline \multicolumn{5}{|l|}{ Folk Sue food } \\
\hline$\geqslant$ Moderate & $13 \mid(55.3)$ & $315(65.5)$ & $0.66(0.48,0.9 \mid)$ & $0.66(0.48,0.91)$ \\
\hline Less, none & $100(43.0)$ & $159(33.0)$ & 1.0 & 1.0 \\
\hline Unknown & $6(2.5)$ & $7(1.5)$ & & \\
\hline \multicolumn{5}{|l|}{ Dairy products } \\
\hline$\geqslant$ Moderate & $104(43.9)$ & I 87 (38.9) & $1.23(0.89,1.68)$ & $1.20(0.87,1.65)$ \\
\hline Less, none & I 32 (55.7) & $291(60.5)$ & 1.0 & 1.0 \\
\hline Unknown & I (0.4) & $3(0.6)$ & & \\
\hline
\end{tabular}

$\overline{\mathrm{OR}}=$ odds ratio; $\mathrm{Cl}=$ confidence interval; Folk Sue food = folk-style vegetarian food.

than that for Chinese Americans (Ross et al, 1981). This is probably due to a higher intake of dietary fat from red meat by Chinese Americans than by men in Taiwan. This may also be partly due to more PSA tests in the US than in Taiwan. There was a long period of economic hardship in Taiwan prior to the industrial development in the 1980s. Increasing consumption of meat began in the 1980s and 1990s. The per capita daily intake of energy from 
Table 3 Odds ratios (95\% confidence intervals) for variables associated with prostate carcinoma among men in Taiwan estimated from multivariate logistic regression models

\begin{tabular}{|c|c|c|c|}
\hline & $\begin{array}{c}\text { Total } \\
\text { OR }(95 \% \mathrm{CI})\end{array}$ & $\begin{array}{c}\text { BMI }>25 \mathrm{~kg} \mathrm{~m}^{-2} \\
\text { OR }(95 \% \mathrm{Cl})\end{array}$ & $\begin{array}{c}\mathrm{BMI} \leqslant 25 \mathrm{~kg} \mathrm{~m}^{-2} \\
\text { OR }(95 \% \mathrm{Cl})\end{array}$ \\
\hline \multicolumn{4}{|l|}{ Age, years } \\
\hline$\geqslant 70$ & $1.42(1.00,2.01)$ & $1.23(0.67,2.25)$ & $1.45(0.94,2.24)$ \\
\hline$<70$ & 1.0 & 1.0 & \\
\hline \multicolumn{4}{|l|}{ Income } \\
\hline High & $2.40(1.07,5.42)$ & $2.61(0.67,10.2)$ & $2.62(0.91,7.50)$ \\
\hline$\leqslant$ Moderate & 1.0 & 1.0 & \\
\hline \multicolumn{4}{|l|}{ Physical activity } \\
\hline High & $1.75(1.08,2.83)$ & $1.63(0.68,3.90)$ & $1.84(1.01,3.34)$ \\
\hline$\leqslant$ Moderate & & & 1.0 \\
\hline \multicolumn{4}{|l|}{$\mathrm{BMI}\left(\mathrm{kg} \mathrm{m}^{-2}\right)$} \\
\hline$\leqslant 25^{\circ}$ & $1.74(1.21,2.51)$ & - & - \\
\hline$>25$ & & & \\
\hline \multicolumn{4}{|l|}{ Married } \\
\hline Yes & $2.49(1.40,4.43)$ & $2.29(0.64,8.23)$ & $2.74(1.42,5.30)$ \\
\hline No & 1.0 & 1.0 & 1.0 \\
\hline \multicolumn{4}{|l|}{ Coffee } \\
\hline Yes & $1.88(1.07,3.30)$ & $2.34(0.91,6.04)$ & $1.91(0.93,3.95)$ \\
\hline No & 1.0 & 1.0 & 1.0 \\
\hline \multicolumn{4}{|c|}{ Folk vegetarian food } \\
\hline$\geqslant$ Moderate & $0.67(0.47,0.94)$ & $1.25(0.66,2.37)$ & $0.50(0.32,0.76)$ \\
\hline Less/none & 1.0 & 1.0 & 1.0 \\
\hline \multicolumn{4}{|l|}{ Fish, shellfish } \\
\hline $\begin{array}{l}\geqslant \text { Moderate } \\
\text { Less/none }\end{array}$ & $\begin{array}{l}1.15(0.79,1.66) \\
1.0\end{array}$ & $\begin{array}{l}2.45(1.14,5.24) \\
1.0\end{array}$ & $\begin{array}{l}0.87(0.56,1.36) \\
1.0\end{array}$ \\
\hline
\end{tabular}

$\mathrm{OR}=$ odds ratio; $\mathrm{Cl}=$ confidence interval; $\mathrm{BMI}=$ body mass index a year prior to diagnosis.

fat in Taiwan increased from $22 \%$ in 1970 to $28 \%$ in 1980 and to $42 \%$ in 1998 (Directorate-General of Budget, 1999). Economic change and longer life expectancy might have an impact on prostate tumorigenesis for men in Taiwan and may explain partly the tripled incidence increase in the last decade.

It is also possible that the greater use of PSA tests in the 1990s for patients with urological complaints may partly explain the increase of the disease in Taiwan. However, no community-based PSA screening has been conducted yet in Taiwan.

Earlier studies have reported an increased risk of prostate carcinoma for men with more children or men who are married (Armenian et al, 1975; Greenwald et al, 1994). Nevertheless, Catholic priests experience no decreased mortality from prostate carcinoma (Ross et al, 1981). Our results showed that men who married or fathering children were at increased risk of developing prostate carcinoma. Most veterans in Taiwan in general get married at later ages and have fewer children or are not married at all because of military service. The higher marital rate and higher rate of being a father in the cases may have been due to the effects of economic prosperity that made having a family easier than for the controls. Some cases married at an earlier age than controls.

Fat intake has been generally thought to increase serum sex hormone levels that may have an association with prostate carcinoma (Parker et al, 1998). The main fat intake in Taiwan is from pork instead of beef. The intake of pork and other types of meat was not significantly different between cases and controls in the present study, neither was the difference in ordinary vegetable consumption.

Nevertheless, the folk vegetarian food provides a protective effect against prostate carcinoma. The tofu and other soybean products, wheat protein, beans, nuts, pickles and plain rice, etc. in the folk vegetarian meals are normally prepared as a 'light' type of diet characterised by less amounts of fat, and no meat and animal fat. About $55 \%$ of cases and $65 \%$ of controls reported being frequent consumers of folk vegetarian meals. Chinese Americans may not have this type of vegetarian food as much as Chinese in Taiwan do. This study showed that men who consumed Taiwanese folk style vegetarian food had a 50\% reduced risk of prostate carcinoma for thin men. Further analysis showed that the consumption of egg and milk together with this type of folk food remains the beneficial effect (data not shown).

The protective effect of the vegetarian meals against the development of prostate carcinoma in this study is consistent with findings in some other studies on the consumption of selected vegetables. Those studies suggest that increased consumption of green leafy vegetables, soybean products, lentils and peas, and tomatoes are associated with decreased prostate carcinoma risk (Mills et al, 1989; Key et al, 1997). These foods are also components served in the Taiwanese folk vegetarian meals. A prospective study of Japanese-Americans in Hawaii suggested that consumption of rice and tofu decreased the risk of prostate carcinoma (Severson et al, 1989). This type of Japanese-American meal is also light, somewhat similar to the Taiwanese folk vegetarian meals. Adlercreutz (1995) has indicated that lignins and the isoflavonoids in soybeans, whole-grain products, various seeds and other similar food components may have an influence on sex hormone metabolism and biological activity. These food items also have an influence on intracellular enzymes, protein synthesis, growth factor action, malignant cell proliferation and angiogenesis, making them protective against carcinoma. It has also been found that vegetarians with high dietary fibre intake excrete large amounts of sex steroids in the faeces, thereby lowering the levels of sex hormones in the plasma (Howie and Schultz, 1985). One of the sex steroids, testosterone, is essential for the normal growth of prostate epithelium, and early stage prostate carcinoma has been shown to be endocrine dependent (Pienta and Esper, 1993).

Some limitations to the present study should be considered. First, recall bias is a drawback in case-control studies. The use of hospital-based controls could decrease differences in health consciousness between cases and controls although using hospital-based controls may also minimise the effect of risk factors. Second, the use of semiquantitative food frequency to quantify diet may not reveal the precise effect of risk factors such as meat and fat consumption. However, its use is very convenient for the elderly with little or no education who must recall the contents of their diet. On the other hand, the folk vegetarian food termed as 'Zhai' or 'Sue' food in Taiwan is easily recalled and counted by lay people regardless of educational levels. Third, due to the use of a binary analysis regarding all risk factors, we might have missed potentially important information such as a dose response. The use of semiquantified data restricts our ability to stratify data into multiple levels. It is also likely that subjects may have underreported their exposure status, but such bias would likely be similar in both cases and controls.

This case-control study showed that prostate carcinoma cases were more likely to occur in educated individuals who engaged in more physical activities and had a lower body mass index. The seemingly protective effect related to the increased intake of folk vegetarian food with very low fat content is particularly significant for thin men.

\section{ACKNOWLEDGEMENTS}

This study was supported by a grant from the National Science Council, Executive Yuan, Taipei, Taiwan (grant \# NSC 087-2314-B002-192). We thank Veterans General Hospital, Taipei for assisting us in this study. 


\section{REFERENCES}

Adlercreutz H (1995) Phytoestrogens: epidemiology and a possible role in cancer protection. Environ Health Prospect 103(Suppl 7): $103-112$

Armenian HK, Lilienfeld AM, Diamond EL, Bross IDJ (1975) Epidemiologic characteristics of patients with prostatic neoplasms. Am J Epidemiol 102: $47-54$

Bostwick DG, Burke HB, Djakiew D, Euling S, Ho SM, Landolph J, Morrison H, Sonawane B, Shiffett T, Waters DJ, Timms B (2004) Human prostate cancer risk factors. Cancer 101(10 Suppl): $2371-2490$

Chyou PH, Nomura AMY, Stemmermann GN (1994) A prospective study of weight, body mass index and other anthropometric measurements in relation to site-specific cancers. Int J Cancer 57: 313-317

Department of Health (2002) Cancer Registry Annual Report, Republic of China, 1999. pp 2-5. Taipei, Taiwan: Department of Health

Directorate-General of Budget (1999) Accountant and Statistics. Republic of China Annual Statistics. Taipei, Taiwan: Executive Yuan. ISSN 10112154, p 122

Doll R, Peto R (1981) The causes of cancer: quantitative estimates of avoidable risks of cancer in the United States today. J Natl Cancer Inst 66: $1192-1308$

Gann PH, Hennekens CH, Sacks FM, Grodstein F, Giovannucci E, Stampfer MJ (1994) Prospective study of plasma fatty acids and risk of prostate cancer. J Natl Cancer Inst 86: 281 - 286

Giovannucci E, Ascherio A, Rimm EB, Stampfer MJ, Colditz GA, Willett WC (1995) Intake of carotenoids and retinol in relation to risk of prostate cancer. J Natl Cancer Inst 87: 1767-1776

Giovannucci E, Rimm EB, Colditz GA, Stampfer MJ, Ascherio A, Chute CC, Willett WC (1993) A prospective study of dietary fat and risk of prostate cancer. J Natl Cancer Inst 85: 1571 - 1579

Greenwald P, Damon A, Kirmss V, Polan AK (1994) Physical and demographic features of men before developing cancer of the prostate. J Natl Cancer Inst 53: $341-346$

Gronberg H, Damber L, Damber J-E (1996) Total food consumption and body mass index in relation to prostate cancer risk: a case-control study in Sweden with prospectively collected exposure data. J Urol 155: 969-974

Howell MA (1974) Factor analysis of international cancer mortality data percapita consumption. $\mathrm{Br}$ J Cancer 29: 328-336
Howie BJ, Schultz TD (1985) Dietary and hormonal interrelationships among vegetarian Seventh-Day Adventists and nonvegetarian men. Am J Clin Nutr 42: $127-134$

Ilic M, Vlajinac H, Marinkovic J (1996) Case-control study of risk factors for prostate cancer. $\mathrm{Br} J$ Cancer 74: $1682-1686$

Key TJA, Silcocks PB, Davey GK, Appleby PN, Bishop DT (1997) A casecontrol study of diet and prostate cancer. Br J Cancer 76: 678-687

Lee IM, Paffenbarger RS, Hsieh CC (1992) Physical activity and risk of prostate cancer among college alumni. Am J Epidemiol 135: $169-179$

Meyer F, Bairati I, Fradet Y, Moore L (1997) Dietary energy and nutrients in relation to preclinical prostate cancer. Nutr Cancer 29: 120-126

Mills PK, Beeson WL, Phillips RL, Fraser GE (1989) Cohort study of diet, lifestyle and prostate cancer in Adventist men. Cancer 64: 598-604

Parker SL, Davis KJ, Wings PA, Ries LAG, Health CW (1998) Cancer statistics by race and ethnicity. CA Cancer J Clin 48: $31-48$

Parkin DM, Pisani P, Ferlay J (1999) Global cancer statistices. CA Cancer J Clin 49: $33-64$

Pienta KJ, Esper PS (1993) Risk factors for prostate cancer. Ann Int Med 118: $793-803$

Ries LAG, kosary CL, Hankey BF, Miller BA, Clegg LX, Edwards BK (1999) SEER Cancer Statistics Review, 1973-1996. pp 419-421. Bethesda, MD: National Cancer Institute. NIH Pub. No. 99-2789

Ross RK, Deapen DM, Casagrande JT, Paganini-Hill A, Henderson BE (1981) A cohort study of mortality from cancer of the prostate in Catholic priests. Br J Cancer 43: 233-235

Severson RK, Nomura AMY, Grove JS, Stemmermann GN (1989) A prospective study of demographics, diet, and prostate cancer among men of Japanese ancestry in Hawaii. Cancer Res 49: 1857-1860

Sung JFC, Lin RS, Pu YS, Chen YC, Chang HC, Lai MK (1999) Risk factors for prostate carcinoma in Taiwan - a case-control study in a Chinese population. Cancer 86: $484-491$

Vlajinac H, Marinkovic J, Ilic M, Kocev NI (1997) Diet and prostate cancer: a case-control study. Eur J Cancer 33: $101-107$

Whittemore AS, Kolonel LN, Wu AH, John EM, Gallagher RP, Howe GR, Burch JD, Hankin J, Dreon DM, West DW, Tsh C-Z, Paffenbarger RS (1995) Prostate cancer in relation to diet, physical activity, and body size in black, whites, and Asians in the United States and Canada. J Natl Cancer Inst 87: $652-661$ 